\title{
Project Based Learning Model Based on Local Wisdom in Citizenship Education Courses to Prevent Radicalism among Students
}

\author{
Abdul Haris Fatgehipon ${ }^{1}$, Saidna Zulfiqar Bin-Tahir ${ }^{2}$, Kamarulnizam Abdullah ${ }^{3}$, Sujarwo ${ }^{4}$, Achmad \\ Nur Hidayat ${ }^{5}$ \\ ${ }^{1}$ Social Studies, Universitas Negeri Jakarta, Jakarta, Indonesia \\ ${ }^{2}$ Education Department, Universitas Iqra Buru, Maluku, Indonesia \\ ${ }^{3,4,5}$ Social Studies, Universitas Negeri Jakarta, Jakarta, Indonesia \\ Email: ${ }^{1}$ harisfatgehipon@gmail.com, ${ }^{2}$ saidnazulfiqar@uniqbu.ac.id, ${ }^{3}$ kamarulnizama@gmail.com, ${ }^{4}$ sujarwo@gmail.com, \\ 5anurhidayat@gmail.com \\ Correspondence to: Email: ${ }^{2}$ saidnazulfiqar@gmail.com
}

\begin{abstract}
The study aimed at developing a project-based learning model based on the local wisdom in the learning process of the citizenship education course. It also aimed at preventing radicalism among students and forming student habits in interpreting local wisdom as a bridge of tolerance. The study employed a research and development (R\&D) design. The subject of the study included 40 PIPS Education students at the State University of Jakarta. The method of collecting data on local wisdom in society that can prevent students from radicalism through observation, questionnaires, interviews, and field notes, then measuring the feasibility of learning model design. Project-based learning used a questionnaire after learning activities are carried out. The results of a questionnaire on the application of project-based learning to the prevention of radicalism obtained an average result of 82 percent of students who strongly agree with the application of the project-based learning model based on the local wisdom, and it can prevent the values of radical times among PIPS students of the Jakarta State University
\end{abstract}

Keywords

Project-based learning, local wisdom, citizenship, radicalism

Article Received: 10 August 2020, Revised: 25 October 2020, Accepted: 18 November 2020

\section{Introduction}

Indonesia, geographically, is a vast archipelago with a diversity of cultures, races, and languages. Iskandar (2016) stated that Indonesia has many islands with high biodiversity and cultural diversity. Sastrapradja, (2010) explained that from the aspect of island diversity, there were no less than 18,110 islands with small and large sizes in Indonesia. However, only 5,707 of them have been named. In the era of the independence struggle, many people doubted whether Indonesia could be integrated into a country. Lestari (2015) argued that Indonesia was a very multicultural country. The Founders of the Republic of Indonesia understand the diversity of Indonesia. It must be a unifying force, not a dividing force. Kansil (2006) argues the philosophy of unity in diversity gives a message to the Indonesian people, and diversity is a force that unites Indonesia. Anugerah and Eadiartia (2018) state that after the Indonesian reformation era, people felt the freedom to be in the age of democratization. Democracy also affected the strength of national integration. It is because various groups and powers have taken the opportunity to build their existence amid freedom after leaving a semi-authoritarian government. Haris (2014) states that democracy can be a cornerstone of the 20-year journey of Indonesian reform, democratic elitism and marginalization of the grassroots, and the discussion of national values' fragility, which is one of the factors for the emergence of radicalism.

Radicalism has become a global issue driving acts of terrorism. It could threaten the Indonesian state. At the individual level, radicalism is present in humans when their environment goes their motivation (Amri et al., 2018). It is a psychological reason why an individual can turn radical, on a broader level; radical has an overall influence by constructing views of the opponent as a threatening identity (McCauley and Moskalenko, 2016). Hilmy (2015) states that the potential for radicalism is determined by individuals not only based on certain ideologies but can take the form of global, regional, and local issues. Ninin Prima Dayanti, et al. (2003) confirmed that there were several radical movements in the society that were built with the same ideological background and tried to oppose the prevailing ideology. Various radicalism movements acting on behalf of the interests of ethnic groups, groups, and religions have sprung up to force their will outside the constitutional channels. In 1999, when Ambon and Poso were hit by the issue of SARA (ethnicity, religion, and race), conflicts with SARA motives occurred in Ambon and North Halmahera, Poso, to Sambas (West Kalimantan) and Sampit (Central Kalimantan) (Hakim, 2014). Many experts predict that Indonesia will experience the threat of disintegration caused by the SARA conflict, it turns out that this hypothesis is not proven, one of the factors that reduce the conflict, namely the Pancasila values that have been formed, is based on the noble values of various ethnic groups in Indonesia that have represented many customs and habits of the people. Indonesia makes it the strength of the Indonesian nation and the values of local wisdom, which become the glue and unifier of society (Sukmayadi, 2018).

It is unfortunate if local wisdom as a unifying force of Indonesian society is not studied academically in higher education, so there is less reference to the theory and 
concepts of Indonesian local wisdom that can resolve various conflicts in culture in Indonesia. Heddy (2009) explains that there are indeed problems in the application of local skills in learning. First, these different local wisdom are still not fully known because they are still "hidden" in the culture and daily life of the people. Second, efforts to find out or explore local wisdom can only be carried out systematically and efficiently if the meaning of the local wisdom itself is clear enough. Third, good knowledge and understanding of local wisdom can only be obtained if research on local wisdom is carried out using appropriate methods and procedures. Even though on the other hand, Suhardi (2019), as the head of the BNPT believes that local wisdom can ward off radicalism. Local wisdom is not only interpreted as art or regional culture, but also for the noble values that apply in the life order of each region. If the government can take advantage of the local wisdom possessed by the people in the area, it will be very effective in warding off radicalism. This is also based on BNPT's research in 2017, which shows that the most substantial deterrence is local wisdom and welfare that local wisdom is considered as the glue between communities (Fatgehipon \& Bin Tahir, 2019).

Student learning activities in the civic education course have not applied direct practice, seeing, observing, and analyzing local wisdom in Jakarta to prevent radicalization. So we need a learning activity that can trigger student practical activities. One form of learning that is considered to be able to explore the potential of local wisdom systematically and efficiently is project-based learning. Project-based learning focuses on the core concepts and principles of the discipline, facilitates students to investigate, find solutions to problems, and other tasks that are meaningful, student-centered, and produce tangible products (Santyasa, 2006). In the application of project-based learning, several steps must be applied. As a first step in implementing project-based learning is a fundamental question and the result is the creation of a student project work (Zakiyah Ismuwardani, et al., 2019). This learning is deemed suitable in developing and exploring the values of local wisdom in-depth to strengthen the character of students in preventing radicalism.

Based on the description of the above problem, this study aims to develop a Project-Based Learning (PBL) learning model that supports students in preventing radicalism and reinforces local wisdom values with the title "Project-based learning model based on local wisdom in civic education courses to prevent radicalism among students."

\section{Method}

This research is a research and development ( R \& D) type of research that aims to develop learning product outcomes. The resulting design is in the form of learning using a project-based learning model based on local wisdom in citizenship course materials to prevent radicalism among students by adopting the Deick \& Carey (2001) model, which consists of: the preliminary stage, the analysis stage, the design stage, the development stage, and testing phase. This research was conducted in the odd semester of the 2020 academic year with a sample of first semester students of the Social Studies Education Study Program, State University of
Jakarta, which involved 40 students as research objects. The methods used in data collection include observation, tests, interviews, questionnaires, and field notes.

Table 1. Data collection methods

\begin{tabular}{|l|l|l|l|l|}
\hline $\begin{array}{l}\text { N } \\
\text { o }\end{array}$ & Target & Method & Instrument & $\begin{array}{l}\text { Subje } \\
\text { ct }\end{array}$ \\
\hline 1. & $\begin{array}{l}\text { Student } \\
\text { responses to } \\
\text { learning models }\end{array}$ & $\begin{array}{l}\text { Questionn } \\
\text { aire }\end{array}$ & $\begin{array}{l}\text { Questionnair } \\
\text { e sheet }\end{array}$ & $\begin{array}{l}\text { Stude } \\
\text { nts }\end{array}$ \\
\hline 2. & $\begin{array}{l}\text { Teachers' } \\
\text { responses to } \\
\text { learning models }\end{array}$ & $\begin{array}{l}\text { Questionn } \\
\text { aire and } \\
\text { Interview }\end{array}$ & $\begin{array}{l}\text { Questionnair } \\
\text { Interview } \\
\text { Sheet }\end{array}$ & $\begin{array}{l}\text { Lectu } \\
\text { rer }\end{array}$ \\
\hline 3. & $\begin{array}{l}\text { Students' } \\
\text { learning } \\
\text { outcome }\end{array}$ & $\begin{array}{l}\text { Test and } \\
\text { task }\end{array}$ & $\begin{array}{l}\text { Testing } \\
\text { material }\end{array}$ & $\begin{array}{l}\text { Stude } \\
\text { nts }\end{array}$ \\
\hline 4. & $\begin{array}{l}\text { Students' } \\
\text { activities }\end{array}$ & $\begin{array}{l}\text { Observati } \\
\text { on and } \\
\text { field notes }\end{array}$ & $\begin{array}{l}\text { Observation } \\
\text { sheet }\end{array}$ & $\begin{array}{l}\text { Stude } \\
\text { nts }\end{array}$ \\
\hline
\end{tabular}

Source: primary data

\section{Results and Discussions}

The implementation of the first activity is a preliminary stage in the form of field studies and literature and analysis. This stage of analysis can be done by conducting field observations and literature studies. At this stage, a focus group discussion (FGD) was also carried out as the first step in defining the learning model that would be carried out with the teaching team, then continued with an analysis in the form of observations to students of the models used in lecture activities that had gone well by applying an active learning model, such as cooperative models, inquiries, and others. Still, in the implementation of learning activities in citizenship courses that have been implemented, students have not expressed themselves in the actualization of learning products. In the next stage, the preparation of a project-based learning model design based on local wisdom and a learning support system is carried out. Learning tools developed include modules, guidelines for using models, lecture units, student activity sheets, and teaching materials. Besides, an assessment instrument was made for students. The assessment carried out related to work results based on projects is a form of work that contains complex tasks starting with very challenging questions and problems and guides students to design, solve problems, make decisions, carry out investigation activities, and provide opportunities for students to work independently.

The next stage is the design, all forms of instruments used in the Project-Based Learning model based on Local Wisdom validated by experts. We are designing how the learning process is carried out, which can then be applied at the implementation stage. The implementation stage refers to Rais in Tutik where there are several steps in the learning model, namely: 1) opening learning with challenging questions, 2) planning projects, 3) compiling a schedule of activities, 4) monitoring the project, 5) assessing the product generated, and 6) evaluation. Referring to the theory, this activity is divided into two groups, the first group is radicalism, which creates conflict between groups, and the 
second group is about radicalism, which causes religious conflict. The stages at each meeting are as follows:

Table 2: Learning implementation activities

\begin{tabular}{|c|c|c|}
\hline $\begin{array}{l}\text { Acti } \\
\text { vitie } \\
\text { s } \\
\text { Phas } \\
\text { es }\end{array}$ & Researchers & Students \\
\hline $\begin{array}{l}\text { Phas } \\
\text { e } 1\end{array}$ & $\begin{array}{l}\text { - Implementing the } \\
\text { division of groups, namely } \\
\text { the first group and the } \\
\text { second group. } \\
\text { - Provide a link } \\
\text { about the attitude of } \\
\text { radicalism that has led to } \\
\text { conflict between groups in } \\
\text { Indonesia and radicalism } \\
\text { caused by religious factors. } \\
\text { - Ask students to } \\
\text { observe and find problems } \\
\text { on the video that has been } \\
\text { shared. Discuss } \\
\text { - the } \\
\text { activities to be carried out } \\
\text { and compile a schedule of } \\
\text { activities. Guide } \\
\text { - and and } \\
\text { facilitate solutions to } \\
\text { problems found in } \\
\text { questions by each group. }\end{array}$ & $\begin{array}{l}\text { - Conduct } \\
\text { discussions and } \\
\text { coordination with } \\
\text { the divided groups. } \\
\text { - Group } 1 \text { : } \\
\text { the theme of inter- } \\
\text { group conflicts that } \\
\text { occurred } \\
\text { Indonesia. } \\
\text { - } \\
\text { the theme of } \\
\text { radicalism caused } \\
\text { by religious } \\
\text { factors. Watch } \\
\text { - } \\
\text { videos that have } \\
\text { been shared. } \\
\text { - Carry out } \\
\text { lectures following } \\
\text { the schedule of } \\
\text { activities that have } \\
\text { been conveyed by } \\
\text { lecturers/researcher } \\
\text { s. } \\
\text { - } \\
\text { existing problems, } \\
\text { discuss and find } \\
\text { solutions. }\end{array}$ \\
\hline $\begin{array}{l}\text { Phas } \\
\text { e } 2\end{array}$ & $\begin{array}{l}\text { - It is monitoring } \\
\text { the activities that students } \\
\text { have carried out. } \\
\text { - Failure } \\
\text { discussion nets conducted } \\
\text { by students, both in } \\
\text { arguments supported by } \\
\text { various reading references } \\
\text { relating to the video } \\
\text { display's issues. } \\
\text { - Conduct } \\
\text { assessment of attitudes } \\
\text { towards students who are } \\
\text { active in discussion } \\
\text { activities. }\end{array}$ & $\begin{array}{l}\text { - } \\
\text { fooking } \\
\text { for various data } \\
\text { sources reinforces } \\
\text { good arguments } \\
\text { because they are } \\
\text { supported by } \\
\text { multiple reading } \\
\text { references related } \\
\text { to the video } \\
\text { question's issues. } \\
\text { - Active in } \\
\text { discussion and } \\
\text { FGD activities in } \\
\text { class groups. }\end{array}$ \\
\hline $\begin{array}{l}\text { Phas } \\
\text { e } 3\end{array}$ & $\begin{array}{l}\text { - Guiding } \\
\text { directing and } \\
\text { equalize perceptions using } \\
\text { a Transdisciplinary } \\
\text { approach where one } \\
\text { problem found is discussed } \\
\text { using several scientific, } \\
\text { social, economic, legal, } \\
\text { and historical methods. }\end{array}$ & $\begin{array}{l}\text { - Equalizin } \\
\mathrm{g} \text { perceptions with } \\
\text { seeking } \\
\text { transdisciplinary } \\
\text { information that is } \\
\text { found to be } \\
\text { discussed using } \\
\text { several scientific } \\
\text { approaches, social } \\
\text { sciences, }\end{array}$ \\
\hline
\end{tabular}

\begin{tabular}{|c|c|c|}
\hline & & $\begin{array}{lr}\text { economics, law, } & \text { and } \\
\text { history, } \\
\text { Indonesian } \\
\text { wisdom. }\end{array}$ \\
\hline $\begin{array}{l}\text { Phas } \\
\text { e } 4\end{array}$ & $\begin{array}{l}\text { Guiding and } \\
\text { facilitating students in the } \\
\text { implementation of the } \\
\text { finalization of making } \\
\text { activity reports. }\end{array}$ & $\begin{array}{l}\text { - Students } \\
\text { finalize activities, } \\
\text { which include } \\
\text { drafting an activity } \\
\text { report consisting of } \\
\text { the results of } \\
\text { discussion of } \\
\text { problems and } \\
\text { solutions to these } \\
\text { problems }\end{array}$ \\
\hline $\begin{array}{l}\text { Phas } \\
\text { e } 5\end{array}$ & $\begin{array}{l}\text { Provide } \\
\text { reinforcement for students } \\
\text { to get to know the values } \\
\text { of Indonesian local } \\
\text { wisdom, which are very } \\
\text { useful in resolving various } \\
\text { conflicts in Indonesia }\end{array}$ & $\begin{array}{l}\text { Provide a } \\
\text { description of the } \\
\text { activity report and } \\
\text { solutions used with } \\
\text { the local wisdom } \\
\text { values approach. }\end{array}$ \\
\hline
\end{tabular}

Source: Primary data

Due to the Covid-19 pandemic, learning cannot be done face-to-face, so student activities in project-based learning research are carried out using social media, including WhatsApp Group, Zoom Meeting, and Google Meet. Even in the atmosphere of the Covid-19 epidemic, the projectbased learning model can be implemented well, despite many limitations, and it is not optimal to measure the project-based learning model to prevent radicalism. The following are the results of the questionnaire assessment in the application of distance learning courses.

Table 3: Percentage of Questionnaire for the Application of

\begin{tabular}{|l|l|l|l|l|l|l|}
\hline $\begin{array}{l}\mathrm{N} \\
\mathrm{o}\end{array}$ & Indicator & $\begin{array}{l}\text { Stro } \\
\text { ngly } \\
\text { Agre } \\
\mathrm{e}\end{array}$ & $\begin{array}{l}\text { Agre } \\
\mathrm{e}\end{array}$ & $\begin{array}{l}\text { Do } \\
\text { ubtf } \\
\text { ul }\end{array}$ & $\begin{array}{l}\text { Disa } \\
\text { gree }\end{array}$ & $\begin{array}{l}\text { Stro } \\
\text { ngly } \\
\text { disa } \\
\text { gree }\end{array}$ \\
\hline 1 & $\begin{array}{l}\text { The attitude of } \\
\text { radicalism is } \\
\text { not following } \\
\text { the values of } \\
\text { Indonesian } \\
\text { social wisdom }\end{array}$ & $22 \%$ & & & \\
\hline 2 & $\begin{array}{l}\text { Radicalism } \\
\text { solutions in } \\
\text { Indonesia are } \\
\text { very } \\
\text { appropriate to } \\
\text { use the local } \\
\text { wisdom } \\
\text { approach }\end{array}$ & $59 \%$ & 31 & 10 & & \\
\hline 3 & $\begin{array}{l}\text { Citizenship } \\
\text { Learning } \\
\text { Less } \\
\text { discussing } \\
\text { Indonesian }\end{array}$ & 74 & 21 & $5 \%$ & & \\
\hline
\end{tabular}




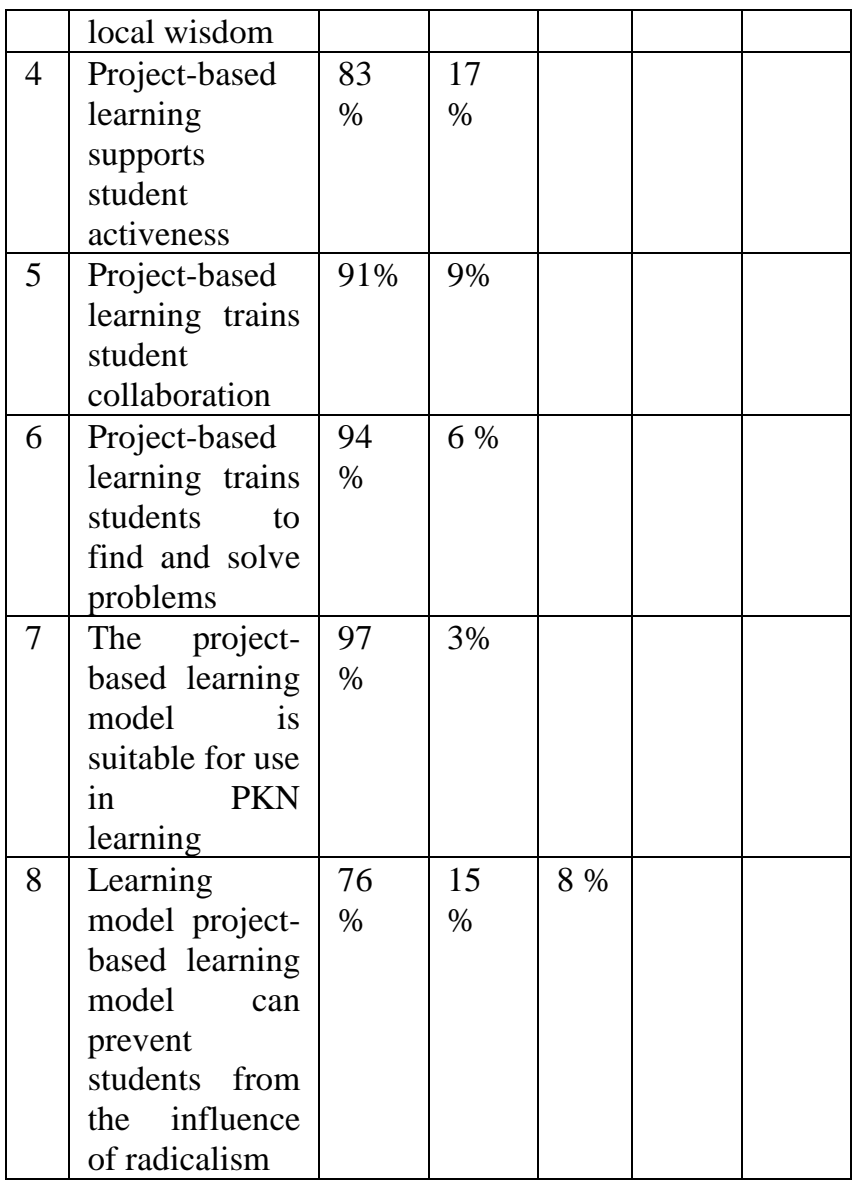

\section{Source: Primary data}

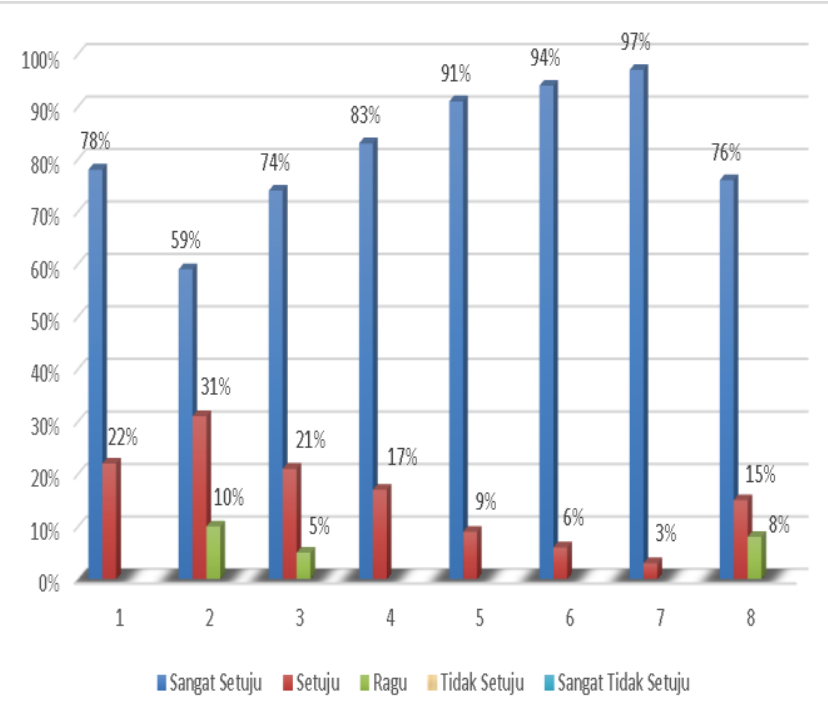

Figure 1.Graph of Percentage of Indicators for the Application of the PBL Model

Based on the graph above, which is adjusted to the indicators in table 3 for indicator one about the attitude of radicalism is not following the value of the local wisdom of the Indonesian nation as much as $78 \%$ of students agree, and $22 \%$ agree, this is reflected in observations in learning activities that show PIPS students UNJ has a good understanding of the local values of Indonesian artistry, such as the importance of deliberation in expressing opinions, speaking politely, avoiding violent ways of expressing ideas. Then for the second indicator, it was obtained that $59 \%$ of students strongly agreed, $31 \%$ agreed, and $10 \%$ were still in doubt in resolving radicalism using the local wisdom approach. This problem can be understood that the public has not seen many examples regarding policies against radicalism with the local wisdom approach. The tendency so far is that the government uses repressive methods, weapons, and laws to crack down on radicalism movements. Furthermore, the 3rd indicator, as many as 74\% of students answered strongly agree, $21 \%$ agreed with citizenship learning, which did not discuss the values of Indonesian local wisdom values, so far many lessons in the national curriculum discussed more the importance of the local cultural culture in Java, The importance of local wisdom outside Java are less addressed in the implementation of learning activities. The 4 th indicator regarding project-based learning strongly supports student activeness obtained by $83 \%$ of students and $17 \%$ who strongly agree. This can be observed in stage 3 . Stage 4 of learning implementation, in following students are very active in discussions during recovery, students find and look for solutions to problems encountered, student participation and activity is very high. Then for the 5th indicator, as many as $91 \%$ of students strongly agree, $9 \%$ agree with project-based learning to train student collaboration, the project-based learning model in practice allows students to work together, discuss finding problems, planning activities, and looking for solutions. For the issues they encountered. Meanwhile, for the 6th indicator, $94 \%$ of students stated that the project-based learning model trains students to find and solve problems. Through the project-based learning program, students can immediately find out problems and find solutions to problems encountered.

From the overall percentage of criteria on the application of project-Based Learning (PBL) learning development using local wisdom, an average value of $82 \%$ of students answered strongly agree and $16 \%$ answered agree that its application in learning activities helps prevent radicalism among students, this can be seen from How students, both in group 1 and group 2 can identify the problems presented and are able to draw a common thread in offering solutions based on the values of Indonesian wisdom such as mutual cooperation, deliberation, mutual respect, polite language speech, must be taught in learning Citizenship. By knowing the values of local wisdom, a student character who is wise, polite, communicative and responsible, and sensitive to issues related to radicalism will be formed.

\section{Conclusion}

Based on the results of the research, it can be concluded that the application of the project-based learning model through the steps of the learning process can increase student activity in civics lectures, who initially have a certain attitude will become active, active in analyzing problems, making plans, and finding solutions to problems. Besides that, with the implementation of local wisdom values, students can better understand radicalism and can solve national problems in a peaceful, humanist, cultured way, not by means of violence. The results of the assessment through questionnaires also show that lecture activities using the PBL model as a basis for learning development get positive results, seen from the results of the feasibility questionnaire, it is obtained that 
$97 \%$ of students who answered strongly agree, $3 \%$ answered agree, this can be concluded that the PBL model is feasible for developed again on larger-scale research.

\section{References}

[1] Anugerah,B \& Edniartia, J.J. 2018. Reorientasi Identitas Demokrasi Indonesia di Era Pasca Reformasi: Sebuah Ikhtiar Mewujudkan Daulat Rakyat. Jurnal Kajian Lemhannas RI, Edisi 34,Juni 2018.

[2] Amri, M., Afifuddin, A., \& Bin-Tahir, S. Z. (2018). Religious Pluralism of the Indonesian Traditional Islamic Education Institutions. The Journal of Social Sciences Research, 4(12), 446-450.

[3] Dick, W., Carey, L. \& Carey, J.O. 2001. The systematic design of instruction (5). New York: Longman.

[4] Fatgehipon, A. H., \& Bin-Tahir, S. Z. (2019). Building Students State Defending Awareness in Preventing the Radicalism. International Journal of Scientific \& Technology Research, 8(10), 3536-3539.

[5] Hakim, M.A (Ed.). 2014. Menyongsong 2014-2019 Memperkuat Indonesia dalam Dunia yang Berubah. Jakarta: Rumah Buku berkerja sama dengan Badan Intelejen Nasional (BIN).

[6] Haris, Syamsuddin. 2014. MasalahMasalah Demokrasi dan Kebangsaan Era Reformasi. Jakarta: Yayasan Pustaka Obor Indonesia.

[7] Heddy Shri, Ahimsa-Putra. 2009. Bahasa, sastra, dan kearifan lokal Di indonesia Mabasan - Vol. 3 No. 1 Januari-Juni 2009: $30-57$

[8] Hilmy, M.. 2015. Radikalisme Agama dan Politik Demokrasi di Indonesia Pasca Orde Baru. MIQOT: Jurnal Ilmu-Ilmu Keislaman.

[9] Iskandar, J. 2016. Etnobiologi dan Keragaman Budaya di Indonesia. ndonesian Journal of Anthropology Volume 1 (1) Juli 2016 eISSN 2528-1569 pISSN 2528-2115.
[10] Kansil, C.S.T. dan S.T Kansil, C. 2006. Modul Pancasila dan Kewarganegaraan. Jakarta: PT. Pradnya Paramita.

[11] Lestari , Gina. (2015). Bhinnekha Tunggal Ika: Khasanah Multikultural Indonesia Di Tengah Kehidupan Sara. Jurnal Pendidikan Pancasila dan Kewarganegaraan, Th. 28, Nomor 1

[12] McCauley, C. and Moskalenko, S.,2016. Friction: How Radicalization Happens To Them and Us. Oxford: Oxford University Press.

[13] Ninin Prima, Damayanti, dkk. 2003. Radikalisme Agama Sebagai Salah Satu Bentuk Perilaku Menyimpang: Studi Kasus Front Pembela Islam. Jurnal Kriminologi Indonesia Vol. 3 No. I Juni $2003: 43-57$

[14] Sastrapradja, S.D. 2010. Memupuk Kehidupan di Nusantara: Memanfaatkan Keragaman Indonesia. Jakarta.

[15] Suhadi Alius. 2019. BNPT: Kearifan Lokal Mampu Tangkal Radikalisme, Republika.co.id, https://republika.co.id/berita/q2ark8366/bn pt-kearifan-lokal-mampu-tangkalradikalisme

[16] Santyasa, I. W. (2006). Pembelajaran Berbasis Masalah dan Pembelajaran Kooperatif . Universitas Pendidikan Ganesha. Nusa Penida.

[17] Sukmayadi, Trisna. 2018. Nilai-Nilai Kearifan Lokal dalam Pandangan Hidup Masyarakat Adat Kampung Kuta : Jurnal Pancasila dan Kewarganegaraan Universitas Muhammadiyah Ponorogo, Vol 3 No 1 : Halaman $19-29$.

[18] Zakiyah Ismuwardani, dkk. 2019, Implementation of Project Based Learning Model to Increased Creativity and SelfReliance of Students on Poetry Writing Skills Journal of Primary Education 8 (1) (2019) : $51-58$. 